\title{
Foraging ranges, diets and feeding locations of gannets Morus bassanus in the North Sea: evidence from satellite telemetry
}

\author{
KC Hamer*, RA Phillips**, S Wanless, MP Harris***, AG Wood*** \\ Department of Biological Sciences, University of Durham, South Road, Durham DH1 3LE, United Kingdom
}

\begin{abstract}
We used satellite telemetry to examine the foraging ranges, feeding locations and travel speeds of 17 chick-rearing gannets Morus bassanus from the Bass Rock, SE Scotland. Regurgitates indicated that birds at the colony exploited a wide range of prey, frequently including 0-group sandeels ( $<10 \mathrm{~cm}$ in length) and mature mackerel and herring (up to $33 \mathrm{~cm}$ ) in the diet. The maximum foraging range was $540 \mathrm{~km}$, and the mean distance to the furthest point from the colony on any one trip was $232 \mathrm{~km}$. Destinations of foraging trips covered a wide area of the North Sea, with a nonrandom distribution and a higher than expected proportion of trips to the NE (generally in the vicinity of Buchan Deep and Halibut Bank) and to the SE (mostly between Farne Deep, Dogger Bank and Outer Silver Pitj of the colony. Foraging trips lasted 13 to $84 \mathrm{~h}$, and trip duration explained $94 \%$ of the variance in maximum distance from the colony, indicating that distance travelled could be predicted with a high degree of accuracy from time spent at sea. However, the average speed of travel during foraging trips $\left(15 \mathrm{~km} \mathrm{~h}^{-1}\right)$ was considerably lower than maximum ground speed $\left(\sim 55 \mathrm{~km} \mathrm{~h}^{-1}\right.$ in most cases). The results of this study suggest that gannets breeding at the Bass Rock utilize a wide range of species and sizes of prey over a large area of the North Sea, and that they focus their activity on bathymetric features that are probably associated with high primary production. Further data are now required to examine the foraging ranges and feeding locations of gannets in different oceanographic regions in order to obtain a broader understanding of how gannets make use of different marine environments.
\end{abstract}

KEY WORDS: Pelecaniformes · Marine distribution $\cdot$ Sandeel $\cdot$ Bathymetry $\cdot$ Flight speed

\section{INTRODUCTION}

Recent concern over the roles of seabirds in marine ecosystems and their interactions with industrial and commercial fisheries has highlighted the need for detailed information on the prey and foraging locations of different species (Tasker \& Furness 1996, Weimerskirch et al. 1999, Thompson \& Hamer 2000). Landbased studies have provided data on diets and prey

•E-mail: k.c.hamer@durham.ac.uk

Present addresses:

-Wildfowì \& Wetlands Trust, Caerlaverock DG1 4RS, UK

"*NERC Institute for Terrestrial Ecology, Hill of Brathens, Banchory AB31 4BY, UK

*.. NERC British Antarctic Survey, Madingley Road, Cambridge CB3 OET, UK harvests (Montevecchi et al. 1992, Phillips et al. 1999), and conventional radio-telemetry has provided information on foraging ranges and feeding sites of inshore feeders (Hamer et al. 1993, Monaghan et al. 1994, Wanless et al. 1997). However, in most cases the movements of pelagic species at sea are only poorly understood. Satellite telemetry provides a means of tracking pelagic species, but to date this technique has been restricted mainly to albatrosses, petrels and penguins in the southern hemisphere (Jouventin \& Weimerskirch 1990, Weimerskirch et al. 1997, Kooyman et al. 1999, Prince et al. 1999, but see Falk \& Møller 1995).

The northern gannet Morus bassanus is the largest pelagic seabird breeding in the North Atlantic (adult body mass = ca $3 \mathrm{~kg}$; Nelson 1978) and has high massspecific energy requirements, resulting in part from high energy expenditure during flight (Birt-Friesen et 
al. 1989). The main prey of gannets are lipid-rich pelagic fish such as mackerel Scomber scombrus, herring Clupea harengus and sandeel Ammodytes marinus (Wanless 1984, Martin 1989). Gannets also compete effectively with other seabird species for discards from commercial fishing vessels (Garthe \& Hüppop 1994, Camphuysen et al. 1995). Tasker \& Furness (1996) estimated conservatively that the annual energy requirement of gannets (including non-breeders but excluding nestlings) in the North Sea was almost $10 \%$ of the total across all seabirds. Despite their relatively small world population, gannets thus have an important potential impact on marine food chains. Moreover they are currently increasing in terms of both population size and geographical distribution (Montevecchi \& Myers 1997, Murray \& Wanless 1997), indicating that this impact is likely to increase further in the future.

A knowledge of the foraging ranges and feeding locations of gannets is essential for quantifying their predator-prey dynamics and for accurately assessing their trophic interactions with industrial fisheries and their likely exposure to risks such as oil pollution and entanglement in fishing gear (Thompson \& Hamer 2000 ). However very little is currently known about the movements of gannets at sea or their foraging ranges. Nelson (1978) suggested a range of 320 to $480 \mathrm{~km}$ from a colony for breeding birds, based on observed trip durations and assuming continuous flight at 65 to $80 \mathrm{~km} \mathrm{~h}^{-1}$, but made no allowance for time spent feeding or resting on the surface, or for deviations from a straight line course. More recently, Tasker et al. (1985) concluded from ship-based surveys that foraging trips rarely exceeded $150 \mathrm{~km}$ from a colony, and that most trips were within $40 \mathrm{~km}$. However, this was likely to be an underestimate, since birds seen at sea were always assumed to be from the nearest breeding colony and because birds feeding in the vicinity of a colony were not distinguished from those commuting between the colony and more distant feeding sites.

One of the largest populations of gannets is on the Bass Rock in the Firth of Forth, SE Scotland $\left(56^{\circ} 6^{\prime} \mathrm{N}\right.$, $\left.2^{\circ} 36^{\prime} \mathrm{W}\right)$. This colony currently contains more than 70000 breeding adults plus several thousand nonbreeders, and is increasing at $\sim 5 \%$ per annum, in common with colonies elsewhere (Murray \& Wanless 1997). During the early 1960s, birds at the Bass Rock fed principally on mackerel (Nelson 1966), but more recent data are not available. There is currently a large fishery for sandeels on the Banks (Wee Bankie and Marr Bank) about $40 \mathrm{~km}$ from the Bass Rock, and concern has been expressed about potential adverse effects of this fishery on local seabirds, including possibly gannets (Wanless et al. 1998). However, it is not known to what extent birds from the Bass Rock currently rely on sandeels as prey or on the Banks as a for- aging location. Based on flight direction, Camphuysen et al. (1995) suggested that birds observed at the Dogger Bank in the central North Sea in May 1994 were from the Bass Rock, but it was not known whether or not these birds were breeding or how regularly birds from the Bass Rock might feed at this site. Breeding birds may have more restricted distributions, making them more sensitive to localized fluctuations in food supply, especially when constrained by the need to provision offspring, but this is not currently known.

This paper provides quantitative information on the diets of gannets at the Bass Rock and uses satellite telemetry to determine the foraging ranges and feeding locations of birds at sea and to estimate both maximum and net travel speeds during foraging trips. To our knowledge this is the first time that satellite telemetry has been used with any seabird during the nestling period in the North Atlantic.

\section{MATERIALS AND METHODS}

Diet. Fieldwork on the Bass Rock took place between 14 June and 28 August 1998. Diet was assessed from regurgitates from adult Morus bassanus. To minimize disturbance, most (246 of 266) samples were collected from birds at the periphery of the colony, the majority of which were likely to be non-breeders. Comparisons of the frequency of occurrence of the main prey items in these samples with 20 known to have come from adults with chicks revealed no evidence of any significant differences in diet between the 2 groups (all $\chi^{2}$ tests, $\mathrm{p}>0.05$ ).

Regurgitates were collected over a period of 2 to $3 \mathrm{~d}$ on each of 6 occasions, spanning the majority of the chick-rearing period at the colony. Each regurgitate was stored separately in a sealed polythene bag and transported to the laboratory, where it was weighed to the nearest $g_{i}$ the prey were identified either visually or from sagittal otoliths and vertebrae extracted from the sample (Härkönen 1986, Watt et al. 1997, authors' pers. obs.). Body length was measured to the nearest $\mathrm{cm}$ (mm for sandeels) or, where this was not possible, was estimated using species-specific body length/ otolith or vertebra length relationships (Härkönen 1986, Watt et al. 1997, authors' pers. obs.). In addition, sandeels were aged by the absence (0-group) or presence (older age groups) of annual growth rings in the otoliths (Anonymous 1995). Dietary data are presented in terms of both frequency of occurrence and the proportions of the total biomass comprised by the different species.

Satellite-tracking of adults. One chick-rearing adult from each of 17 nests with hatching dates \pm 2 wk from the mode was captured at the nest using a roach pole 
with a brass noose. A platform terminal transmitter (PTT; Microwave Telemetry Inc., Columbia, USA) weighing $30 \mathrm{~g}(\sim 1 \%$ of adult mass $)$ and with a dutycycle of continuous transmission was then attached with self-amalgamating tape (RS Components, Newcastle, UK) to the underside of the 4 central tail feathers, close to the base of the tail, with the aerial pointing upwards through the feathers. This arrangement minimized drag during flight and prevented tags being displaced during plunge-diving. Attachment of tags took $\sim 5 \mathrm{~min}$, and after release every bird returned to the nest almost immediately. Each bird was then tracked for 14 to $21 \mathrm{~d}$ (mean = $16 \mathrm{~d}$ ) over a period of $45 \mathrm{~d}$ (11 July to 25 August 1998), after which the tag was removed and the bird weighed to the nearest $10 \mathrm{~g}$ with a Salter spring balance.

Data provided by PTTs were processed using the ARGOS facility (CNES, Toulouse, France). In some cases (when location class is better than Class 0), the system can provide information on the accuracy of locations ( $\mathrm{SD} \pm 150 \mathrm{~m}$ to $1 \mathrm{~km}$ ). However, in many cases (Location Classes $0, A$ and $B$ ) this information is not available. Thus, the accuracy of these locations was assessed using occasions when birds were known to be at the colony (152 locations of Class 0,150 of Class A and 187 of Class B). On these occasions, SD of the distance from the colony (calculated from Eq. 1 below) was 2.2, 6.9 and $34.0 \mathrm{~km}$ for Classes $0, A$ and $B$, respectively. We thus used only locations of Class A or better, giving us a maximum SD for each location of $6.9 \mathrm{~km}$, which was small compared to the distances travelled by the birds (see 'Trip durations and destinations' below).

Locations of birds at sea were overlaid on a universal transverse Mercator projection using GIS Arcview. In order to estimate distances travelled by birds, we used the following equation to calculate the arc distance, $D$, between pairs of locations (here designated $A$ and $B$ ):

$$
\cos D=(\sin a \sin b)+(\cos a \cos b \cos L)
$$

where $a=$ latitude of Location $A, b=$ latitude of Location $\mathrm{B}$ and $L=$ degrees of longitude between Locations $\mathrm{A}$ and B. $D$ was then converted from an arc distance in radians to a distance in $\mathrm{km}$ by multiplying by the radius of the earth (6370.9 km; Robinson et al. 1978).

A series of locations within $5 \mathrm{~km}$ of the colony were assumed to pertain to birds at their nests, as indicated by direct observations. This assumption may have resulted in our missing some trips of short duration by birds that stayed close to the colony, but direct observations indicated that such trips were rare and did not result in delivery of food to the chick. Durations of foraging trips were calculated from the time of the first location after a bird had left the colony until the time of the first location after it had returned. Such calculations were made only for trips with at least 8 locations $\mathrm{d}^{-1}$, giving an average error of $\pm 3 \mathrm{~h}$ for departure and arrival times. Average travel speed during each of these trips was calculated as twice the slope of the linear regression of maximum distance from the colony upon trip duration.

To examine movements over shorter intervals within the total foraging ranges of the birds, we estimated travel speeds during short sections of each trip as the distance between consecutive pairs of locations divided by the time elapsed between them. In view of maximum SDs on locations, very short intervals between locations could produce erroneous estimates of speed. To avoid this problem we used only pairs of locations at sea separated by intervals of $>1 \mathrm{~h}$.

Potential effects of PTTs on adults. We examined the potential impacts of PTTs on both foraging-trip durations and body masses of adults. To examine foragingtrip durations, nest-attendance patterns of chick-rearing adults at 45 control nests from the same part of the colony as those birds fitted with PTTs were recorded continuously from a hide throughout daylight hours (4:00 to 22:00 h) on 3 occasions between 15 June and 26 July. Data were not recorded during hours of darkness, when there was little activity in the colony and birds were unlikely to have returned or departed (Nelson 1978, Garthe et al. 1999). On each occasion, we recorded the number of changeovers in parental attendance at the nest each day. Changeovers took only a few minutes to complete, and chicks were not left unattended during this period. Accordingly, the frequency of changeovers was used to estimate trip durations (following Hamer et al. 1993), for comparison with birds fitted with PTTs. On some occasions, the adults made short flights (up to $30 \mathrm{~min}$ ), after which the chick was not fed, before departing the colony. We therefore recorded birds as having departed on a foraging trip only if they were absent from the nest for $>30$ min. Although adults were not marked individually, arrivals were always loud and conspicuous (Nelson 1978), and so we are confident that we did not miss any arrivals and subsequent changeovers in nest attendance.

To examine potential impacts of PTTs on adult body mass, a control sample of 40 chick-rearing adults from nearby nests was weighed over a similar period and compared to those that had been carrying PTTs for the previous 14 to $21 \mathrm{~d}$ (27 July to 25 August).

\section{RESULTS}

\section{Diet}

We obtained a total of 266 regurgitates from adult Morus bassanus. Of these, $76 \%$ contained 1 species of 
prey and $24 \%$ contained 2 species (generally occupying different portions of the sample and so probably ingested separately). From these 266 samples, the main prey in terms of frequency of occurrence were mackerel, sandeels (mainly 0-group), sprat Sprattus sprattus and herring, with Gadidae and other species present at lower frequency (Table 1). The total biomass regurgitated was $27.3 \mathrm{~kg}$ comprising, in order of abundance, mackerel, herring, sandeel, Gadidae, sprat and other species (Table 1). Estimates of the sizes of prey taken indicated that these varied markedly in size, from 0-group sandeels (mean $=7.8 \mathrm{~cm}$ ) to haddock $(29.1 \mathrm{~cm})$ and trout $(34.0 \mathrm{~cm}$; Table 2$)$.

Table 1. Diets of gannets Morus bassanus at Bass Rock in 1998 , based on a biomass of $27.3 \mathrm{~kg}$ from 266 regurgitates. Gadidae were mainly haddock Melanogrammus aeglefinus, whiting Merlangius merlangus and cod Gadus morhua. Other species were plaice Pleuronectes platessa, salmon Salmo salar, trout $S$. trutta, grey gurnard Eutrigla gurnadus, garfish Belone belone, greater forkbeard Phycis blenoides. Prey presented in order of decreasing importance

\begin{tabular}{|lcc|}
\hline Species & $\begin{array}{c}\text { Frequency of } \\
\text { occurrence (\%) }\end{array}$ & $\begin{array}{c}\text { Proportion of } \\
\text { biomass (\%) }\end{array}$ \\
\hline Mackerel & 31.6 & 30.8 \\
Herring & 21.5 & 20.3 \\
Sandeel & 29.3 & 17.9 \\
0-group & 27.0 & 12.5 \\
Older & 2.3 & 5.4 \\
Sprat & 23.0 & 12.6 \\
Gadidae & 15.0 & 16.4 \\
Others & 3.7 & 2.1 \\
\hline
\end{tabular}

Table 2. Lengths $(\mathrm{cm})$ of fish eaten by gannets Morus bassanus at Bass Rock in 1998

\begin{tabular}{|c|c|c|c|c|c|}
\hline Species & $\mathrm{n}$ & Mean & SE & Min. & Max. \\
\hline \multicolumn{6}{|l|}{ Sandeel $^{\mathrm{a}}$} \\
\hline 0-group & 2016 & 7.8 & 0.02 & 5 & 10 \\
\hline Older & 432 & 11.6 & 0.07 & 9 & 17 \\
\hline Sprat $^{\mathrm{a}}$ & 375 & 9.8 & 0.08 & 5 & 15 \\
\hline Herring & 53 & 20.7 & 0.55 & 10 & 30 \\
\hline Mackerel & 42 & 24.9 & 0.68 & 15 & 33 \\
\hline Haddock & 15 & 29.1 & 1.61 & 18 & 37 \\
\hline Whiting & 12 & 26.9 & 1.54 & 18 & 34 \\
\hline Cod & 4 & 26.2 & 3.29 & 20 & 30 \\
\hline $\begin{array}{l}\text { Unidentified } \\
\text { gadoid }\end{array}$ & 8 & 18.0 & 1.83 & 12 & 24 \\
\hline Flattish & 9 & 21.3 & 1.76 & 12 & 27 \\
\hline Grey gurnard & 3 & 13.0 & 1.00 & 11 & 16 \\
\hline Salmon & 2 & 26.0 & 0 & 26 & 26 \\
\hline Trout & 1 & 34.0 & - & - & - \\
\hline $\begin{array}{l}\text { Greater } \\
\text { forkbeard }\end{array}$ & 1 & 25.0 & - & - & - \\
\hline \multicolumn{6}{|c|}{${ }^{\circledR}$ Based on all otoliths extracted from samples } \\
\hline
\end{tabular}

\section{Movements of adults during foraging trips}

We obtained a total of 1327 locations of Class A and above (up to 14 locations $\operatorname{tag}^{-1} \mathrm{~d}^{-1}$ with a mean of 6 locations $\operatorname{tag}^{-1} \mathrm{~d}^{-1}$ ), of which $68 \%$ were at sea and $32 \%$ at the colony. Less than $2 \%$ of locations were over the mainland (Fig. 1), and these were all well within $1 \mathrm{SD}$ of distance from the coast. Locations covered a wide area of the North Sea (Fig. 1), extending as far as Halibut Bank (NE Scotland), Bergen/Viking Bank (West Norway), Fisher Bank (north central North Sea) and beyond Dogger Bank (south central North Sea; see Fig. 3 for locations of these features) with a maximum range of $540 \mathrm{~km}$ and a mean distance (excluding locations at the nest) of $164 \mathrm{~km}$ ( $\mathrm{SD} \pm 101$ ) from the colony. Nearly all locations were east of the Bass Rock, with only $4 \%$ west of the colony in the Firth of Forth.

\section{Trip durations and destinations}

There were 72 foraging trips spread over all 17 tagged birds, with locations at average intervals of $\leq 3 \mathrm{~h}$, allowing reasonably accurate assessment of the routes taken by birds. To illustrate these, 2 typical routes taken by adults are shown in Fig. 2 . We used the furthest recorded location from the colony during each of these 72 trips to provide information on trip destinations. The mean duration of these trips was $32.2 \mathrm{~h}$ ( $\mathrm{SD} \pm 13.2$, range $=13.1$ to $84.0 \mathrm{~h})$, and the mean distance to destination was $232 \mathrm{~km}$ (SD \pm 100 , range $=39$ to $540 \mathrm{~km}$ ). Destinations had a highly non-random distribution (proportion of trips in each of 7 consecutive sectors, each subtending an angle of $20^{\circ}$ at the colony; $\chi_{6}^{2}=19.3, p=0.004$ ), with more trips to the NE and SE and fewer trips due east of the colony than would be expected by chance (Fig. 3). Destinations NE of the Bass Rock (19\% of the total) were generally in the vicinity of the Buchan Deep and Halibut Bank (Fig. 3). Destinations SE of the colony (71\%) were mostly between the Farne Deep, Outer Silver Pit and Dogger Bank, with a small proportion ( $4 \%$ of destinations) east of Dogger Bank. Only $10 \%$ of destinations were due east of the colony, comprising $7 \%$ in the vicinity of Devil's Hole and 3\% at Wee Bankie and Marr Bank (Fig. 3).

There was a highly significant relationship between maximum distance from the colony and trip duration (Fig. $4 ; F_{1,67}=988.7, \mathrm{p}<0.0001, \mathrm{R}^{2}=0.94$ ), according to the following equation:

Maximum distance $(\mathrm{km})=$

$$
7.05(\mathrm{SE} \pm 0.22) \text { trip duration }(\mathrm{h})
$$

Average speed over complete foraging trips was thus equal to $14.1(\mathrm{SE} \pm 0.4) \mathrm{km} \mathrm{h}^{-1}$ (twice the slope of Eq. 2). 


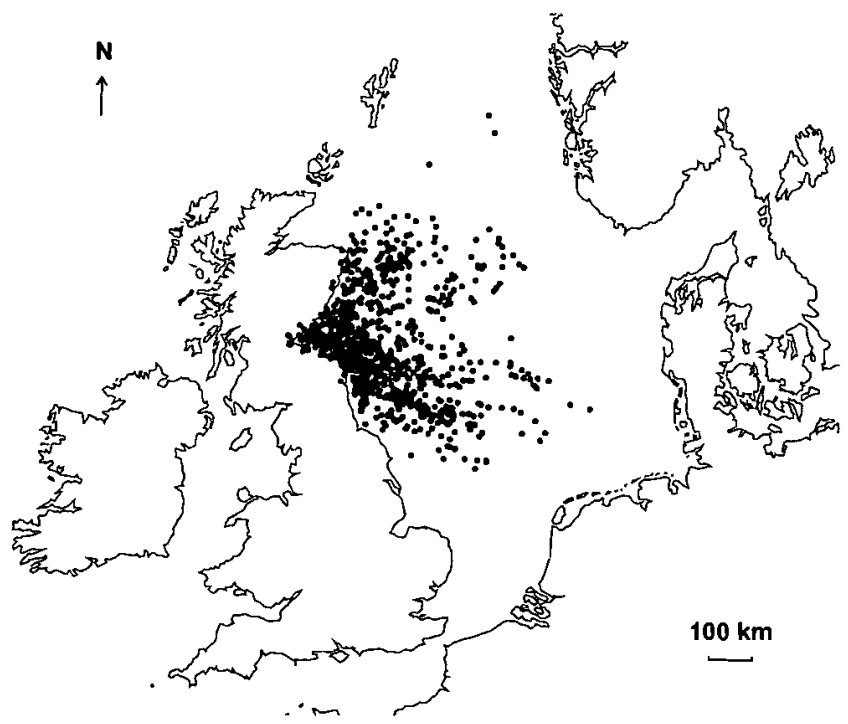

Fig. 1. Morus bassanus. Foraging range of gannets from Bass Rock, SE Scotland, based on 1327 locations (all recorded locations of Class A and above; see 'Materials and methods' for explanation) from 17 chick-rearing adults over period of $45 \mathrm{~d}$

Speeds of travel over intervals within trips were calculated using consecutive pairs of locations at sea with $>1 \mathrm{~h}$ between them (see 'Materials and methods Satellite tracking of adults'). The mean of these values was $18.1 \mathrm{~km} \mathrm{~h}^{-1}(\mathrm{n}=797, \mathrm{SD} \pm 16.6)$, which was similar to the mean over entire trips. The mean speed during hours of darkness (23:00 to $4: 00 \mathrm{~h}$ ) was very low (1.6 km $\mathrm{h}^{-1}, \mathrm{n}=30, \mathrm{SD} \pm 1.9$ ), indicating that birds did not fly at night; the mean speed during daylight was substantially higher $\left(22.3 \mathrm{~km} \mathrm{~h}^{-1}, \mathrm{n}=767, \mathrm{SD} \pm 31.6\right.$; MannWhitney $Z=5.82, \mathrm{p}<0.0001$ ). Speed of travel during hours of daylight was highly dependent on the interval between locations (linear regression; $F_{1,765}=132.9, \mathrm{p}<$ $0.0001, R^{2}=0.16$ ), according to the following equation:

Travel speed $\left(\mathrm{km} \mathrm{h}^{-1}\right)=$

$$
28.4(\mathrm{SE} \pm 0.9)-1.9(\mathrm{SE} \pm 0.1) \text { interval }(\mathrm{h})
$$

The maximum ground speed recorded was $81 \mathrm{~km}$ $\mathrm{h}^{-1}$, but only $1 \%$ of values were $>68 \mathrm{~km} \mathrm{~h}^{-1}$ and only $5 \%$ were $>56 \mathrm{~km} \mathrm{~h}^{-1}$ (Table 3 ).

\section{Impacts of PTTs on adults}

There was no difference in body mass between control birds (mean $=2.89 \mathrm{~kg}, \mathrm{n}=40, \mathrm{SD} \pm 0.23$ ) and birds that had been carrying PTTs for up to $21 \mathrm{~d}$ (mean = $2.93 \mathrm{~kg}, \mathrm{n}=16, \mathrm{SD} \pm 0.24$; Student's $t$-test using pooled variance estimate; $t_{54}=0.6, p=0.6$ ). There was an average of 0.87 changeovers per nest per day at control nests, giving a mean trip duration of $27 \mathrm{~h}$. This was no

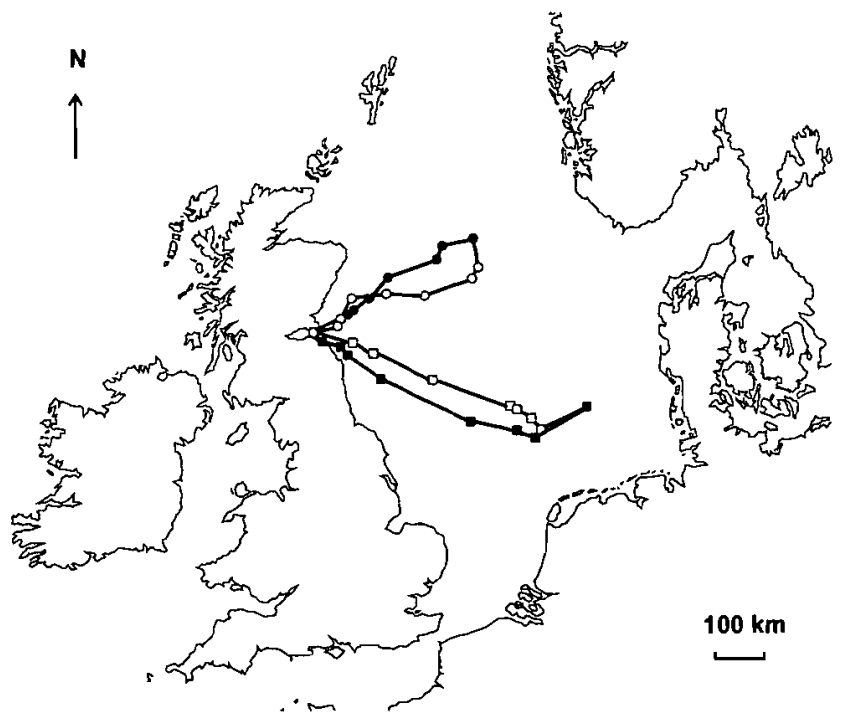

Fig. 2. Morus bassanus. Examples of typical routes taken on foraging trips by chick-rearing gannets from Bass Rock. (a) outward path; (ㅁ) return path

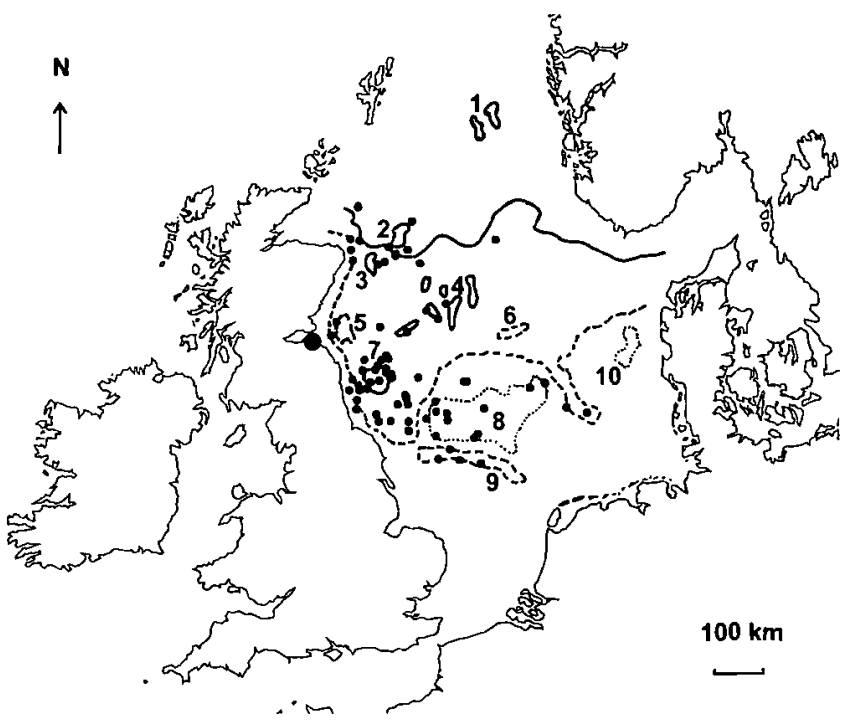

Fig. 3. Morus bassanus. Destinations of foraging trips by chick-rearing gannets at Bass Rock. Based on 72 trips from 17 adults with data received at average intervals of $<3 \mathrm{~h}$. Major bathymetric features of North Sea within foraging range of adults are also illustrated. Isobaths redrawn from UK Admiralty International Charts 2182B [Central North Sea) and 2182C (Northern North Sea). (—) $100 \mathrm{~m}$. $(\cdots \cdots) 50 \mathrm{~m},(\cdots \cdots \cdots \cdots) 30 \mathrm{~m} .1$ 1: Bergen/Viking Bank, 2: Halibut bank, 3: Buchan Deep, 4: Devil's Hole, 5: Wee Bankie/Marr Bank, 6: Fisher Bank, 7: Farne Deep, 8: Dogger Bank, 9: Outer Silver Pit, 10: Jutland Bank 


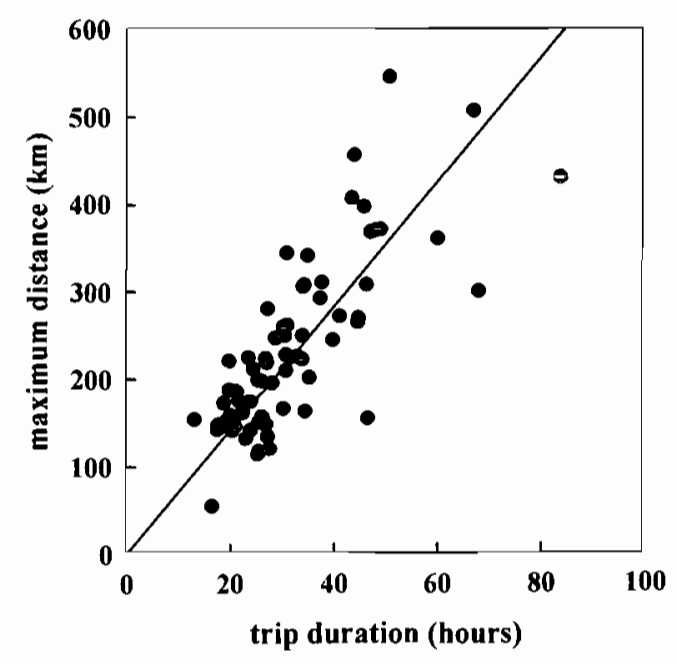

Fig. 4. Morus bassanus. Relationship between maximum distance from colony and foraging trip duration

Table 3. Morus bassanus. Frequency distribution of travel speed at sea $(n=797)$, for gannets breeding on the Bass Rock in 1998

\begin{tabular}{|lccc|}
\hline $\begin{array}{l}\text { Travel speed } \\
\left(\mathrm{km} \mathrm{h}^{-1}\right)\end{array}$ & Frequency & $\begin{array}{c}\% \text { of } \\
\text { cases }\end{array}$ & $\begin{array}{c}\text { Cumulative } \\
\%\end{array}$ \\
\hline $00.1-10.0$ & 323 & 40.5 & 40.5 \\
$10.1-20.0$ & 211 & 26.5 & 67.0 \\
$20.1-30.0$ & 98 & 12.3 & 79.3 \\
$30.1-40.0$ & 70 & 8.8 & 88.1 \\
$40.1-50.0$ & 42 & 5.3 & 93.4 \\
$50.1-60.0$ & 32 & 4.0 & 97.4 \\
$60.1-70.0$ & 14 & 1.8 & 99.1 \\
$70.1-80.0$ & 6 & 0.8 & 99.9 \\
$80.1-90.0$ & 1 & 0.1 & 100.0 \\
\hline
\end{tabular}

different from the frequency of changeovers for birds fitted with PTTs $\left(0.75\right.$ per nest per day; $\chi^{2}{ }_{2}=4.74, \mathrm{p}=$ 0.1 ), which resulted from a mean trip duration of $32 \mathrm{~h}$.

\section{DISCUSSION}

\section{Collection of data}

Trip durations of Morus bassanus wearing PTTs did not differ from those of untagged controls, and the body masses of tagged birds after 14 to $21 \mathrm{~d}$ did not differ from those of controls (see 'Results'), indicating that attachment of satellite tags did not adversely affect birds' foraging behaviour. Birt-Friesen et al. (1989) found that handling of gannets had some adverse effects on nest attendance, but in their study birds were held in captivity for $>4 \mathrm{~h}$ and recaught up to 3 times between 1 and $7 \mathrm{~d}$ after initial capture, whereas in the current study capture of birds and fitting with
PTTs took only 5 min on average, and birds were handled only once prior to data collection. The lower proportion of high-quality (Class $\mathrm{A}$ and above) locations for the colony than for birds at sea in our study (see 'Results') probably resulted from poorer visibility of the tags to orbiting satellites when the birds were on land, rather than because tagged birds spent more time at sea than on land.

Mean trip durations in this study were considerably longer than those recorded in some previous studies (see Table 6 in Nelson 1978, Garthe et al. 1999), but were similar to those recorded by Wanless $(1981 ; 18$ to $24 \mathrm{~h})$. Variation in mean trip durations presumably reflects differences in the distribution of marine food resources around different colonies. Nelson (1978) recorded that gannets at the Bass Rock can sometimes make foraging trips of 2 to $3 \mathrm{~d}$ duration, indicating that trips in the present study were not abnormally long.

Nelson (1966) recorded an average of 2.7 foraging trips per nest per day at the Bass Rock in the early 1960s, indicating a mean trip duration of $\sim 9 \mathrm{~h}$ compared with an estimated $27 \mathrm{~h}$ using the same methods in 1998 (see 'Results - Impacts of PTTs on adults'). This difference in trip duration suggests that prey availability in the vicinity of the colony may have been substantially lower in 1998 than during the early 1960s, and this is supported by the poor breeding success of several species of seabirds at nearby colonies in 1998 (S.W. \& M.P.H. unpubl. data).

\section{Foraging range and feeding locations}

The foraging range of adults covered a wide area of the North Sea, up to a maximum distance of $540 \mathrm{~km}$ (Fig. 1) with a mean distance of $230 \mathrm{~km}$ to the furthest point from the colony on any one trip (Fig. 3). Tasker et al. (1985) suggested a much shorter maximum range $(150 \mathrm{~km})$, although this was based on the assumption that birds observed at sea were always from the colony nearest to the point of observation. Thus, birds observed between the Farne Deep and Dogger Bank were assumed to be all from the colony at Flamborough Head, NE England, whereas the current study indicates that this part of the North Sea is also an important foraging area for birds from the more distant colony at the Bass Rock (Fig. 3).

The results of this study confirm the suggestion by Camphuysen et al. (1995) that birds observed at Dogger Bank in early summer included individuals breeding at the Bass Rock. In addition to Dogger Bank, destinations of foraging trips included a number of other bathymetric features including Halibut Bank, Buchan Deep, Farne Deep and Outer Silver Pit (Fig. 3), possibly reflecting enhanced primary production at inter- 
faces between mixed shallow water and deeper stratified water (Begg \& Reid 1997, Schneider 1997). Gannets may to some extent have utilized these sites in association with fishing vessels (Garthe \& Hüppop 1994).

The large foraging range and wide variation in species and sizes of prey utilized by gannets from the Bass Rock (from 0-group sandeel to mature herring and mackerel; Tables 1 \& 2) suggests that they are better buffered against reductions in food supply than most other seabird species in the North Sea. Thus, despite an apparent 3 -fold increase in trip duration since the 1960s and very low productivity of other species breeding at colonies in the Firth of Forth in 1998, survival of gannet chicks was high ( $-80 \%$ at study nests) and chicks appeared to be growing normally during the study. Martin (1989) similarly found that gannets in Shetland responded to a major reduction in their main prey (sandeels) by switching to alternative prey, with no apparent reduction in productivity. In this study, although sandeels constituted almost $20 \%$ of prey by mass, only a small proportion of trips were to the Wee Bankie and Marr Bank, suggesting that gannets are unlikely to be greatly affected by the current sandeel fishery there.

\section{Speed of travel during foraging trips and relation- ship between trip duration and foraging range}

The maximum estimated ground speed in this study $\left(80 \mathrm{~km} \mathrm{~h}^{-1}\right)$ was equal to the maximum flight speed suggested by Nelson (1978), but occurred only very rarely (Table 3). In total, 95\% of estimated travel speeds were below $56 \mathrm{~km} \mathrm{~h}^{-1}$, suggesting that the maximum ground speed normally attained by gannets is $\sim 55 \mathrm{~km} \mathrm{~h}^{-1}$. This is very close to the flight speed of $54 \mathrm{~km} \mathrm{~h}^{-1}$ recorded by Pennycuick (1987).

Travel speed decreased significantly with increasing time intervals between locations (Eq. 3), as also found by Hull et al. (1997) for royal penguins Eudyptes schlegeli. This relationship presumably results from travel speeds over longer intervals being more affected by deviations from a straight-line course and by time that birds spend feeding and resting on the water. Over the shortest intervals, where estimates are least affected by deviations from a straight-line course, the mean travel speed in this study was $28.4 \mathrm{~km} \mathrm{~h}^{-1}$ (from Eq. 3). This was close to half the normal flight speed (55 $\mathrm{km} \mathrm{h}^{-1}$; see previous paragraph), indicating that birds spent roughly half their time at sea in flight. Garthe et al. (1999) also found, from external temperature loggers, that birds spent about half their time away from the colony in flight and the other half on the sea surface.
Durations of foraging trips are generally assumed to give a good indication of distances flown by birds, although there is little evidence to support this assumption and increasing evidence to the contrary, at least for short-distance foragers (Cairns 1987, Becker et al. 1993, Monaghan et al. 1994). For gannets, trip duration explained $94 \%$ of the variance in maximum distance from the colony, indicating that distance travelled could be predicted with a high degree of accuracy from trip duration. However, the average speed of travel during foraging trips $\left(14 \mathrm{~km} \mathrm{~h}^{-1}\right.$, from Fig. 4) was considerably lower than the maximum flight speed. Thus, previous estimates of foraging range as the product of flight speed and trip duration (e.g. Nelson 1978) are likely to have been overestimates.

The results of this study suggest that gannets breeding at the Bass Rock are able to exploit a wide range of species and prey sizes over a large area of the North Sea, and that they focus their activity upon bathymetric features that are probably associated with high primary production. Comparative data are now required to examine the foraging ranges and feeding locations of gannets in different oceanographic regions in order to obtain a broader understanding of how gannets make use of different marine environments.

Acknowledgements. This study was supported by grants from the European Commission Fisheries Directorate (CEC 96-079 and 95/C 76/15) and JNCC (F90-01-154). We thank Sir Hew Hamilton-Dalrymple for access to the Bass Rock, John Croxall for assistance in developing the project, and Bryan Nelson for logistic support and advice. We thank Fiona Stewart, Chris Coles, Claire McSorley, Kate Buchanan, John Yearsley, Fiona Thom, Sue O'Brien, Stuart Bearhop and Bryan Nelson for assistance with collection of data. We thank Suki Finney for analysis of food samples and Jane Hill for help with production of maps.

\section{LITERATURE CITED}

Anonymous (1995) Review of sandeel biology. Int Counc Explor Sea Comm Meet 1995/9:4 (Rep ICES Workshop on Sandeel Otolith Analysis)

Becker PH, Frank D, Sudmann SR (1993) Temporal and spatial pattern of common tern (Sterna hirundo) foraging in the Wadden Sea. Oecologia 93:389-393

Begg GS, Reid JB (1997) Spatial variation in seabird density at a shallow sea tidal mixing front in the Irish Sea. ICES J Mar Sci 54:552-565

Birt-Friesen VL, Montevecchi WA, Cairns DK, Macko SA (1989) Activity-specific metabolic rates of free-living northern gannets and other seabirds. Ecology 70:357-367

Cairns DK (1987) Diet and foraging ecology of black guillemots in northeastern Hudson Bay. Can J Zool 65: $1257-1263$

Camphuysen CJ, Heessen HJL, Winter CJN (1995) Distant feeding and associations with cetaceans of gannets Morus bassanus from the Bass Rock in May 1994. Seabird 17: $36-43$ 
Falk K, Møller S (1995) Satellite tracking of high-Arctic northern fulmars. Polar Biol 15:495-502

Garthe S, Hüppop O (1994) Distribution of ship-following seabirds and their utilization of discards in the North Sea in summer. Mar Ecol Prog Ser 106:1-9

Garthe S, Grémillet D, Furness RW (1999) At-sea activity and foraging efficiency in chick-rearing northern gannets (Sula bassana): a case study in Shetland. Mar Ecol Prog Ser 185:93-99

Hamer KC, Monaghan P, Uttley JD, Walton P, Burns MD (1993) The influence of food supply on the breeding ecology of kittiwakes Rissa tridactyla in Shetland. lbis 135: $255-263$

Härkönen T (1986) Guide to the otoliths of the bony fishes of the Northeast Atlantic. Danbiu ApS, Hellerup, Denmark

Hull CL, Hindell MA, Michael K (1997) Foraging zones of royal penguins during the breeding season, and their association with oceanographic features. Mar Ecol Prog Ser 153:217-228

Jouventin $P$, Weimerskirch $H$ (1990) Satellite tracking of wandering albatrosses. Nature 343:746-748

Kooyman GL, Hull C, Olsson O, Robertson G, Croxall JP, Davis LS (1999) Foraging patterns of polar penguins. In Adams NJ, Slotow RH (eds) Proceedings of the 22nd International Ornithology Congress, Durban. BirdLife South Africa, Johannesburg, p 2021-2039

Martin AR (1989) The diet of Atlantic puffin Fratercula arctica and northern gannet Sula bassana chicks at a Shetland colony during a period of changing prey availability. Bird Study 36:170-180

Monaghan $\mathrm{P}$, Walton $\mathrm{P}$, Wanless $\mathrm{S}$, Uttley JD, Burns MD (1994) Effects of prey abundance on the foraging behaviour, diving efficiency and time allocation of breeding guillemots Uria aalge. Ibis 136:214-222

Montevecchi WA, Myers RA (1997) Centurial and decadal oceanographic influences on changes in northern gannet populations and diets in the north-west Atlantic: implications for climate change. ICES J Mar Sci 54 : 608-614

Montevecchi WA, Birt-Friesen VL, Cairns DK (1992) Reproductive energetics and prey harvest of Leach's stormpetrels in the northwest Atlantic. Ecology 73:823-832

Murray S, Wanless S (1997) The status of the gannet in Scotland 1994-95. Scottish Birds 19:10-27

Nelson JB (1966) The breeding biology of the gannet Sula bassana on the Bass Rock, Scotland. Ibis 108:584-626

Nelson JB (1978) The gannet. T \& AD Poyser, Berkhamstead

Pennycuick CJ (1987) Flight of auks (Alcidae) and other northern seabirds compared with southern Procellari-

Editorial responsibility: Otto Kinne (Editor),

Oldendorf/Luhe, Germany iformes: ornithodolite observations. J Exp Biol 128: 335-347

Phillips RA, Thompson DR, Hamer KC (1999) The impact of predation by great skuas on seabird populations at St Kilda: a bioenergetics model. J Appl Ecol 36:218-232

Prince PA, Weimerskirch H, Wood AG, Croxall JP (1999) Areas and scales of interactions between albatrosses and the marine environment: species, populations and sexes. In: Adams NJ, Slotow RH (eds) Proceedings of the 22nd International Ornithology Congress, Durban, Johannesburg, South Africa, BirdLife South Africa, p 2001-2020

Robinson A, Sale R, Morrison J (1978) Elements of cartography. John Wiley \& Sons, New York

Schneider DC (1997) Habitat selection by marine birds in relation to water depth. Ibis 139:175-178

Tasker ML, Furness RW (1996) Estimation of food consumption by seabirds in the North Sea. ICES Co-op Res Rep 216:6-42

Tasker ML, Jones PH, Blake BF, Dixon TJ (1985) The marine distribution of the gannet in the North Sea. Bird Study 32: $82-90$

Thompson DR, Hamer KC (2000) Stress in seabirds: causes, consequences and diagnostic value. J Mar Ecosyst Stress Recovery (in press)

Wanless S (1981) The gannets of Boreray. In: Duncan N, Bullock D, Taylor K (eds) The Boreray 1980 expedition - a report on the ecology and natural history of St Kilda. University of Durham, Durham, p 26-28 (unpubl. expedition rep)

Wanless S (1984) The growth and food of young gannets Sula bassana on Ailsa Craig. Seabird 7:62-70

Wanless S, Bacon PJ, Harris MP, Webb AD, Greenstreet SPR, Webb A (1997) Modelling environmental and energetic effects on feeding performance and distribution of shags (Phalacrocorax aristotelis): integrating telemetry, geographical information systems, and modelling techniques. ICES J Mar Sci 54:524-544

Wanless S, Harris MP, Greenstreet SPR (1998) Summer sandeel consumption by seabirds breeding in the Firth of Forth, south-east Scotland. ICES J Mar Sci 55:1141-1151

Watt J, Pierce GJ, Boyle PR (1997) Guide to the identification of North Sea fish using premaxillae and vertebrae. ICES Co-op Res Rep 220:1-231

Weimerskirch $\mathrm{H}$, Cherel $\mathrm{Y}$, Cuenot-Chaillet $\mathrm{F}$, Ridoux V (1997) Alternative foraging strategies by male and female wandering albatrosses. Ecology 78:2051-2063

Weimerskirch $\mathrm{H}$, Catard A, Prince PA, Cherel T, Croxall JP (1999) Foraging white-chinned petrels Procellaria aequinoctalis at risk: from the tropics to Antarctica. Biol Conserv 87:273-275

Submitted: August 20, 1999; Accepted: December 1, 1999 Proofs received from author(s): June 8,2000 